\title{
PHF6 wt Allele
}

National Cancer Institute

\section{Source}

National Cancer Institute. PHF6 wt Allele. NCI Thesaurus. Code C101450.

Human PHF6 wild-type allele is located in the vicinity of Xq26.3 and is approximately $56 \mathrm{~kb}$ in length. This allele, which encodes PHD finger protein 6 , is involved in the regulation of transcription. Mutation of the gene is associated with Borjeson-Forssman-Lehmann syndrome. 